\title{
Permanent and temporary ponds in Doñana National Park (SW Spain) are threatened by desiccation
}

\author{
Carmen Díaz-Paniagua and David Aragonés
}

Estación Biológica de Doñana-CSIC, Avda. Americo Vespucio s/n, 41013 Sevilla, Spain. poli@ebd.csic.es, daragones@ebd.csic.es

* Corresponding author: poli@ebd.csic.es

Received: 09/01/2014 Accepted: 16/06/2015

\begin{abstract}
Permanent and temporary ponds in Doñana National Park (SW Spain) are threatened by desiccation

In Doñana National Park, most aquatic habitats are temporary. Ponds dry up during the summer, and are filled again when phreatic levels rise after heavy rains. Permanent and semipermanent ponds, and a chain of long-hydroperiod ponds are formed in an area of the park where discharges of the dune and regional aquifers coincide.

Over the last few decades, groundwater abstractions have severely affected the park. Using Landsat images (1975-2014), we estimated the variation in the inundated areas of the park's largest ponds. All ponds have increased their dependency on annual rainfall in recent decades. Two seasonal ponds located close to urban pumping stations are currently dry. We found that other seasonal ponds have tended to have shorter hydroperiod and have dried up in the summer in recent years, including in very rainy years. The largest permanent pond had not such wide interannual fluctuations in its inundated area in the 1970s as those experienced recently. During the last decades, its inundated area is strongly correlated with annual rainfall, and the pond is close to desiccation in years of low rainfall.
\end{abstract}

These results show that this pond network is severely threatened by desiccation. It is urgent to control groundwater extraction in the area to preserve the integrity of this important wetland.

Key words: Ponds, conservation, Doñana, groundwater, overexploitation, remote sensing, Landsat.

\section{RESUMEN}

\section{Amenazas de desecación de las lagunas temporales y permanentes de Doñana}

En Doñana, la mayoría de los hábitats acuáticos son temporales. Las lagunas se desecan en verano y vuelven a inundarse con la elevación del nivel freático que se produce tras las abundantes lluvias otoñales o invernales. En la zona central del parque se localizan las lagunas permanentes y semipermanentes, que junto con otras de largo hidroperiodo forman una cadena de lagunas donde coinciden las descargas del acuifero dunar y el gran acuífero regional.

En las últimas décadas, se han realizado extracciones de agua del acuífero que han afectado seriamente al parque. En este estudio, usando imágenes del satélite Landsat (1975-2014), hemos estimado la variación de la superficie inundada de las mayores lagunas del parque. En todas se observa un incremento en las últimas décadas de su dependencia de las lluvias anuales. Dos lagunas estacionales, situadas en las proximidades de estaciones de bombeo de aguas se consideran actualmente secas. En algunas lagunas, se observa una tendencia a acortar su periodo de inundación, secándose en los veranos de los años más recientes, incluso en años lluviosos. La laguna más permanente no sufría tan amplias variaciones en la superficie que mantenía inundada en verano en los años 70 , como las que observan en la actualidad, cuando su inundación en verano está estrechamente correlacionada con las lluvias anuales, llegando en los últimos veranos a niveles muy próximos a la desecación.

Estos resultados indican que la red de lagunas está severamente amenazada de desecación. Para preservar la integridad de este importante humedal, es urgente controlar las extracciones de agua del acuífero.

Palabras clave: Lagunas, conservación, Doñana, aguas subterráneas, sobreexplotación acuífero, teledetección, Landsat. 


\section{INTRODUCTION}

Wetlands are important aquatic habitats that contribute to the conservation of a large number of species. The conservation status of wetlands is largely determined by the dynamics of their water sources, which are, in many cases, threatened by anthropogenic impacts. For instance, wetlands that mainly depend on groundwater resources may be threatened by aquifer exploitation. When groundwater abstraction surpasses sustainable levels, it may result in a decline of the water table, thus affecting the hydrologic regimes of connected wetlands: their inundation periods (i.e. hydroperiods) may be reduced or they may even dry up entirely (Llamas \& Garrido, 2007). Doñana National Park harbours one of the most important wetlands in Europe. This wetland comprises a large, seasonal marsh, underlain by impermeable clayey substrates as well as an extensive pond network that has formed on a sandy permeable substrate. In this network, pond inundation levels directly reflect the levels of the groundwater in the aquifer (Sacks et al., 1992). The Spanish government acknowledged the importance of Doñana's aquatic habitats when it created the park in 1969, thus affording the maximum legal protection possible to the area. Doñana National Park was designated a UNESCO Biosphere Reserve in 1981, Ramsar site and Natura Special Protection Area in 1982, and a UNESCO World Heritage site in 1994. The park has also, on several occasions, been awarded the European Diploma for Protected Areas from the Council of Europe. As a consequence of all this recognition, the preservation of this area has received special attention. National and international commissions have repeatedly written reports about its conservation status. Since Doñana is a wetland, the most important resources to protect are water quantity and quality. The hydrologic regimes of most of the ponds in Doñana are influenced by seasonal fluctuations in the extensive aquifer, which spans about $3400 \mathrm{~km}^{2}$ (Manzano \& Custodio, 2006). Groundwater has been extracted from this aquifer over the last decades to fuel intensive agriculture and to supply some towns and villages, resulting in severe drawdown in particular areas of the park (CGS, 2008; Custodio et al., 2009).

Doñana's pond network contains more than 3000 temporary ponds that vary greatly in size and hydroperiod (Gómez-Rodriguez et al., 2011). In contrast, permanent ponds are rare and are exclusively found in the centre of the park, in an area where discharges from the local aquifer and the regional aquifer coincide. Together with some large seasonal ponds also found in this area, they form a chain of the largest ponds in the park. Located nearby is a beach resort, Matalascañas, whose water supply comes from groundwater withdrawals; it was founded around 1967 and underwent a major expansion in the 1990s. A golf course was even built in 2000. The development that has taken place in Matalascañas over the last few decades can be seen in figure S1 (available in the supplementary information at www.limnetica.net/net).

Doñana has received advice regarding the environmental threats and risks the park is facing; this advice has included specific recommendations related to the need to limit groundwater abstraction in order to preserve aquatic habitats. Indeed, Doñana has been included in the Montreux Record since 1990, a register that lists Ramsar sites where changes in ecological character associated with human interference threaten its conservation. Several missions have since then provided assistance and made recommendations with a view to addressing the main threats to the park that still in 2014 is included in the record. A group of experts from the WWF/IUCN/ADENA visited Doñana in 1988. They specifically underscored the risks presented to the largest ponds by the decline of the water table in this area due to Matalascañas' water consumption (estimated at that time to be $1.6 \mathrm{hm}^{3}$ for human use plus $2 \mathrm{hm}^{3}$ for garden irrigation). They concluded that water extraction by Matalascañas was having a major effect on its nearby ponds and could even ultimately cause their desiccation (Hollis et al., 1989). In 1992, another group of experts reached the same conclusion and recommended that the volume of water being withdrawn should be reduced by limiting garden irrigation and grass-intensive 
landscaping, such as golf courses (except if they could be maintained using depurated waters that do not pollute groundwaters). Furthermore, they suggested that Matalascañas' pumping stations should be located farther away from the chain of ponds. Another report, conducted after complaints were lodged with UNESCO, stated that water supply for Matalascañas could lead to pond desiccation and the decline of piezometric levels. It highlighted that this ecosystem could deteriorate if water withdrawals persisted (Comisión Internacional de Expertos, 1992; García-Novo, 1994). In 2005, an ambitious plan was carried out to restore Doñana's natural hydrology; it included steps to reestablish the water dynamics of the park's marshes and some of its streams by providing water of sufficient quality in sufficient quantities (García-Novo \& Marín, 2006). However, this plan did not address groundwater-related problems.

Groundwater hydrodynamics in Doñana have been extensively studied using a network of piezometers. Researchers have found that a major decline in the water table is taken place in certain parts of the park as a result of agricultural irrigation or to abstractions for urban water supply (Vela et al., 1991; Manzano et al., 2001; CGS, 2008; Custodio et al., 2009). The effects of intensive groundwater pumping in this area have been described. Under natural conditions, water recharges should have descendent flows and then raise locally and discharge to ponds and wetlands. However, intensive groundwater pumping has reversed the flows in groundwater, and nowadays in perturbed areas, such as near the Matalascañas pumping stations, water recharges have only descendent flows towards the deepest aquifer (Custodio \& Palancar, 1995). These changes may reduce pond hydroperiod and may even lead to pond desiccation. A dramatic reduction in the water levels of several ponds found near Matalascañas has been observed (Serrano \& Serrano, 1996; Coleto, 2003, Serrano \& Zunzunegui, 2008); furthermore, terrestrial

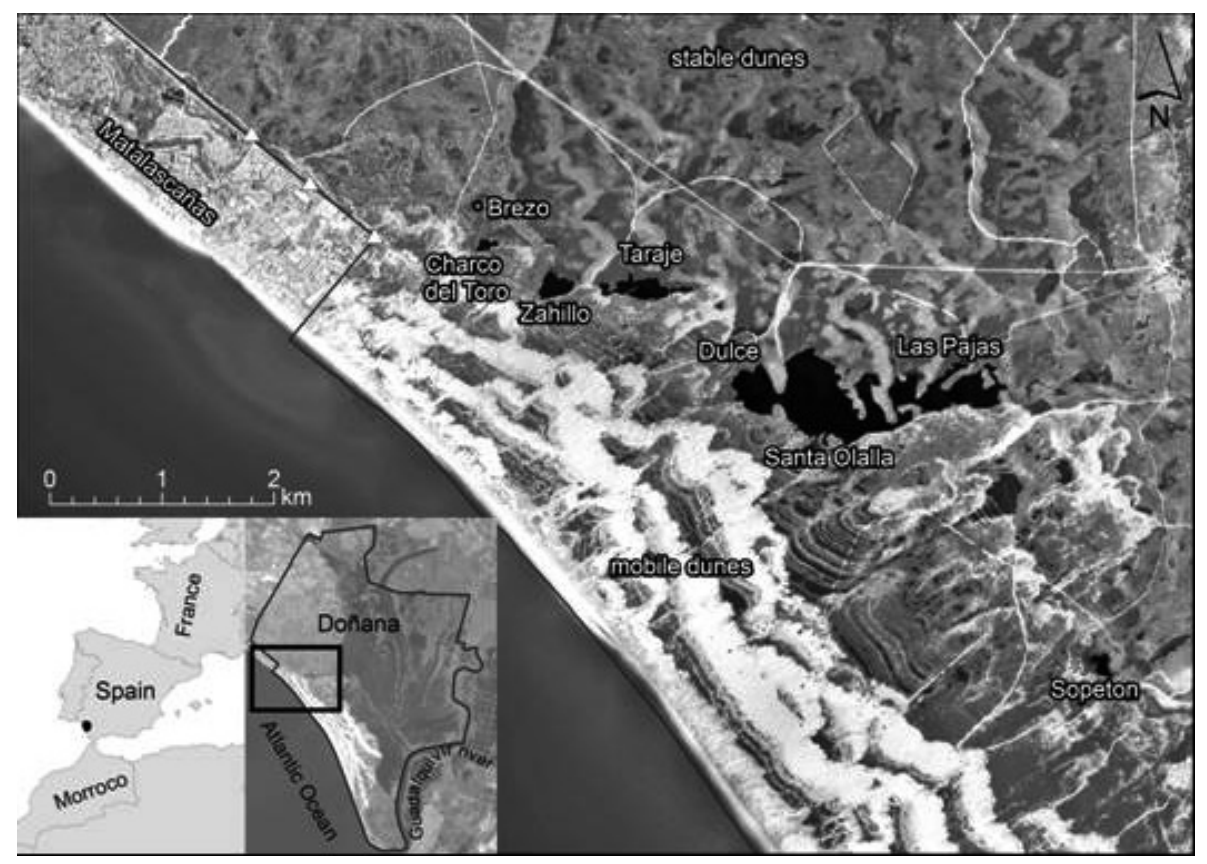

Figure 1. Map of the study area. The urban resort (Matalascañas) is located in the west, close to the chain of peridune ponds (Brezo, Charco del Toro, Zahillo, Taraje, Dulce, Santa Olalla, Las Pajas) located between mobile dunes and stable dunes. The last pond included in this study, Sopetón, is located about two kilometers further south. Mapa del área de estudio. La urbanización turística (Matalascañas) está situada al oeste, cerca de la cadena de lagunas peridunares (Brezo, Charco del Toro, Zahillo, Taraje, Dulce, Santa Olalla, Las Pajas, que se localizan entre las dunas móviles y las arenas estabilizadas. La última laguna, El Sopetón, está a unos dos km hacia el sur. 
vegetation has invaded the basins of these ponds (Zunzunegui et al., 1998; Muñoz-Reinoso, 2001; Serrano \& Zunzunegui, 2008). The hydrodynamics of Doñana's largest ponds have previously been described in detail. Because these ponds are surface-level expressions of the underground water table, changes in the elevation of the water table directly affect pond levels and size (Sacks et al., 1992). In the more permanent ponds, rainfall is the major water input during the wet season, whereas it is groundwater seepage during the dry season. In dry years, the water table does not rise and therefore groundwater flow reversals towards the ponds do not occur. As a result, pond volumes are low and ponds act as recharge areas instead of discharge of the aquifer (Sacks et al., 1992). The more seasonal ponds are also dependent on groundwater. The hydrodynamics of Charco del Toro pond, which only receives water in very rainy years, are considered to have been severely impacted by water abstraction by Matalascañas (Coleto, 2003).

Intensive monitoring of Doñana's aquifer has been carried out over the last few decades. Unfortunately, no information has been gathered on variation in the depth and inundation areas of the park's temporary and permanent ponds, except for occasional short time periods (Coleto, 2003;
Lozano 2004). Without this information, it is difficult to understand how water table declines are affecting the status of Doñana ponds, and the development of management strategies that could help restore the hydrodynamics of these wetlands has been delayed.

Because there are not historical field data available on how the water level of Doñana's ponds vary, in this study we used remote sensing data to assess pond inundation areas over time. One of the advantages of using remote sensing data is that radiometric values, which are consistent and based on reproducible methods, can be digitally and automatically analyzed. By using Landsat satellite images, our study exploited the longest and most consistent historical source of satellite images for the study area. Our aim was to assess variation in the inundation areas of Doñana's largest and most permanent ponds to detect if the pond network is currently facing desiccation risks. We hypothesised that the observed declines in the water table similarly affected the pond's inundation regimes, which we examined through their inundation areas particularly in summer. Due to the proximity of the ponds to Matalascañas, that have experienced a wide expansion in the last 25 years, and include a golf course since 2000 , we also pretend to evi-

Table 1. Main characteristics of the study ponds: inundated area, altitude, hydrological regimes, distance to Matalascañas pumping stations, approximate maximum depth, and percentage of years in which the pond dried out in the summer. The hydrological regimes include a first value estimated in relation to the percentage of years in which each pond was dry, and a second value, which corresponds to the trends observed in the last years of the study period (not shown when it did not change). Inundated area is taken to be the estimated area given in Gómez-Rodríguez et al. (2011). The area of the desiccated pond, Brezo, was estimated using the isolines corresponding to a basin determined by a digital elevation model. Principales características de las lagunas estudiadas: área inundada, altitud, régimen hidrológico, distancia a las estaciones de bombeo de Matalascañas, profundidad máxima aproximada y porcentaje de años en que se han secado en verano. El régimen hidrológico incluye un primer valor obtenido a partir del porcentaje de años en que se seca cada laguna, y un segundo valor que corresponde a las tendencias observadas en los últimos años del estudio (no se muestra si no cambia). El área inundada corresponde a la estimada en Gómez-Rodríguez et al. (2011); para la laguna del Brezo, seca durante el periodo de estudio, se estima el área correspondiente a las isolíneas que corresponderían a la cubeta obtenida a partir de un modelo digital de elevaciones.

\begin{tabular}{lcccccc}
\hline Pond name & Distance to Pumps & Altitude (masl) & Hydrological regime & Inundated area (ha) & Depth (m) & $\%$ years dry \\
\hline Brezo & $750 \mathrm{~m}$ & 14 & Seasonal/desiccated & $(1.2)$ & 1.3 & 100 \\
Charco del Toro & $718 \mathrm{~m}$ & 10 & Seasonal/desiccated & 1.4 & 0.9 & 85.2 \\
Zahillo & $1313 \mathrm{~m}$ & 8 & Seasonal & 4.8 & 0.7 & 75.0 \\
Taraje & $1830 \mathrm{~m}$ & 7.6 & Seasonal & 8.1 & 0.8 & 80.8 \\
Dulce & $3235 \mathrm{~m}$ & 4.6 & Permanent/semipermanent & 12.3 & $1.1-1.7$ & 18.6 \\
Santa Olalla & $3720 \mathrm{~m}$ & 3.4 & Permanent & 45.5 & $2.5-3.4$ & 3.7 \\
Pajas & $4580 \mathrm{~m}$ & 4.4 & Seasonal & 23.8 & 1.1 & 81.4 \\
Sopetón & $7158 \mathrm{~m}$ & 1.7 & Permanent/semipermanent & 2.3 & 0.7 & 37.0 \\
\hline
\end{tabular}


dence that it has an additional effect on the closer ponds, causing the desiccation or increasing their trends of desiccation.

\section{METHODS}

\section{The study area}

Doñana National Park is located in southwestern Spain, between the mouth of Guadalquivir River and the Atlantic Ocean. This area has an Atlantic influenced Mediterranean climate, characterized by hot, dry summers and rainfall that occurs mostly in the autumn or winter. One half of the park is a seasonal marsh, and the other half is a sandy area that includes mobile and stable dunes (a geomorphological description can be found in Siljestrom et al., 1994). In the sandy area, more than 3000 temporary ponds appear in rainy years (Díaz-Paniagua et al., 2010; Gómez-Rodriguez et al., 2011). Doñana's aquatic systems have been described in detail in Serrano et al. (2006), remarking important differences in relation to the geomorphology of their basins. The hydrodynamics of the pond network are influenced by the high permeability of the substrate underlying the ponds and the proximity of groundwater. A large aquifer system under an area of about $3400 \mathrm{~km}^{2}$ supports most of the park's aquatic habitats, especially the ponds located on sandy substrates, which result from aquifer discharges in areas where local topography intercepts the water level (Manzano \& Custodio, 2006). Most of the ponds in Doñana are temporary, and their inundation-desiccation cycles track seasonal variation in groundwater levels.

It is very difficult to detect desiccation trends associated with temporary ponds because pond level vary greatly from year to year, including dry periods during which groundwater levels may reach different depth in different years. Consequently, to analyze the variability in the park's hydrological regime, we studied the largest and more permanent ponds of the park. While most of Doñana's ponds are medium- or small- sized temporary ponds, there is a chain of large ponds located within the ecotone that has formed in the area where stable dunes come in contact with mobile dunes (Fig. 1). This area includes the park's most permanent ponds, which are formed by the confluence of discharges from the regional aquifer and the local dune aquifer (Coleto, 2003) and are located in a sequential order along the regional groundwater flow that also approximately correspond with a decreasing gradient in height. The ponds in this chain are called peridune ponds and include both large seasonal ponds that hold water in the summers of very wet years and permanent ponds that have dried out only after periods of prolonged drought. A description of these ponds is provided in Table 1. These peridune ponds are located near a beach resort village called Matalascañas. There is at least 10 pumping stations that extract water from the aquifer to supply the village. The last one is located approximately $700 \mathrm{~m}$ from the closest peridune pond. The volume of water reported

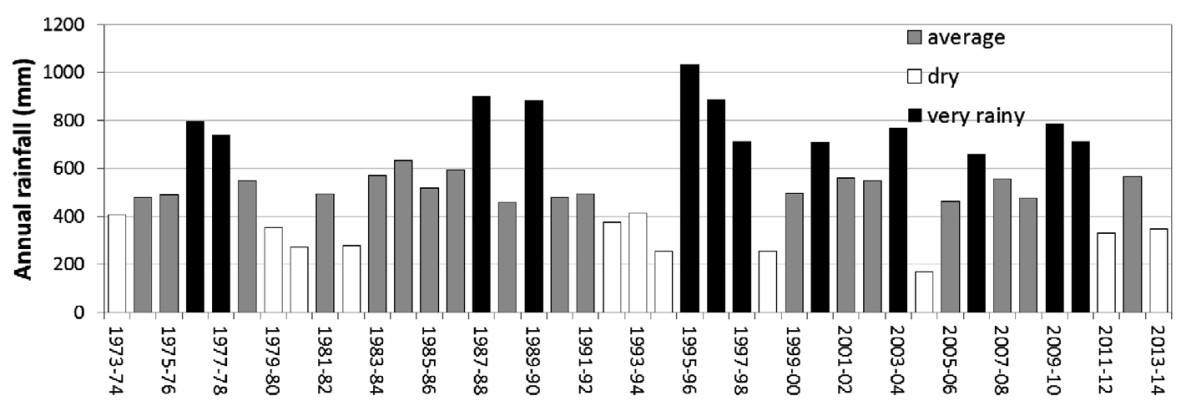

Figure 2. Variation in annual rainfall from 1973-74 to 2013-14. Each annual period begins on October 1 and ends on September 30 of the following year. Variación de las lluvias anuales desde el año 1973-74 hasta el 2013-14. Cada año incluye desde el 1 octubre hasta el 30 de septiembre del siguiente año. 
to be pumped is around $2.3 \mathrm{Hm}^{3} / \mathrm{yr}$ (Data provided in 2013 from the Water Supply offices to Confederación Hidrográfica del Guadalquivir). However, similar or even higher quantities (2.5-3.0 $\mathrm{Hm}^{3} / \mathrm{yr}$ ) were reported to be extracted in the 1990's decade (Muñoz-Reinoso, 2001).

\section{Remote sensing data}

We have compiled more than 340 available cloud free Landsat Multi Spectral Scanner (MSS), Tematic Mapper (TM) and Enhanced Tematic Mapper (ETM+) images for Doñana (scene in track 217 (MSS) or 202 (TM-ETM+) frame 034), covering the 1975-2014 period. In order to make all them comparable, we applied a consistent pre-processing (The list of images used is shown in Table S1 y S2, available in the supplementary information at www.limnetica.net/net).

A 2002 Landsat 7 ETM+ reference image from summer with clear sky conditions was geo- referenced using 100 ground control points over aerial orthophotos (Junta de Andalucía, 2003). The remaining TM and ETM+ images were coregistered to this reference image. Resampling method was cubic convolution. Root mean square (RMS) error calculated with an independent test point sample on co- registered images was 19.7 $\mathrm{m}$. All Images were then radiometrically corrected and transformed into reflectance values using Pons \& Solé-Sugrañes (1994) method implemented in MiraMon $\triangle($ Pons, 2004). Finally reflectance images were normalized to the reference image using a set of pseudo-invariant areas covering all the range of reflectance values present in the scene, comprising over 60000 pixels and selected from eight different area types that were expected to have low seasonal changes in reflectance (e.g. deep sea, reservoirs, rocky outcrops, sand dunes, bare soils, urban areas). We calculated a cloud mask and pseudo-invariant pixels were rejected if covered by clouds (Busta-
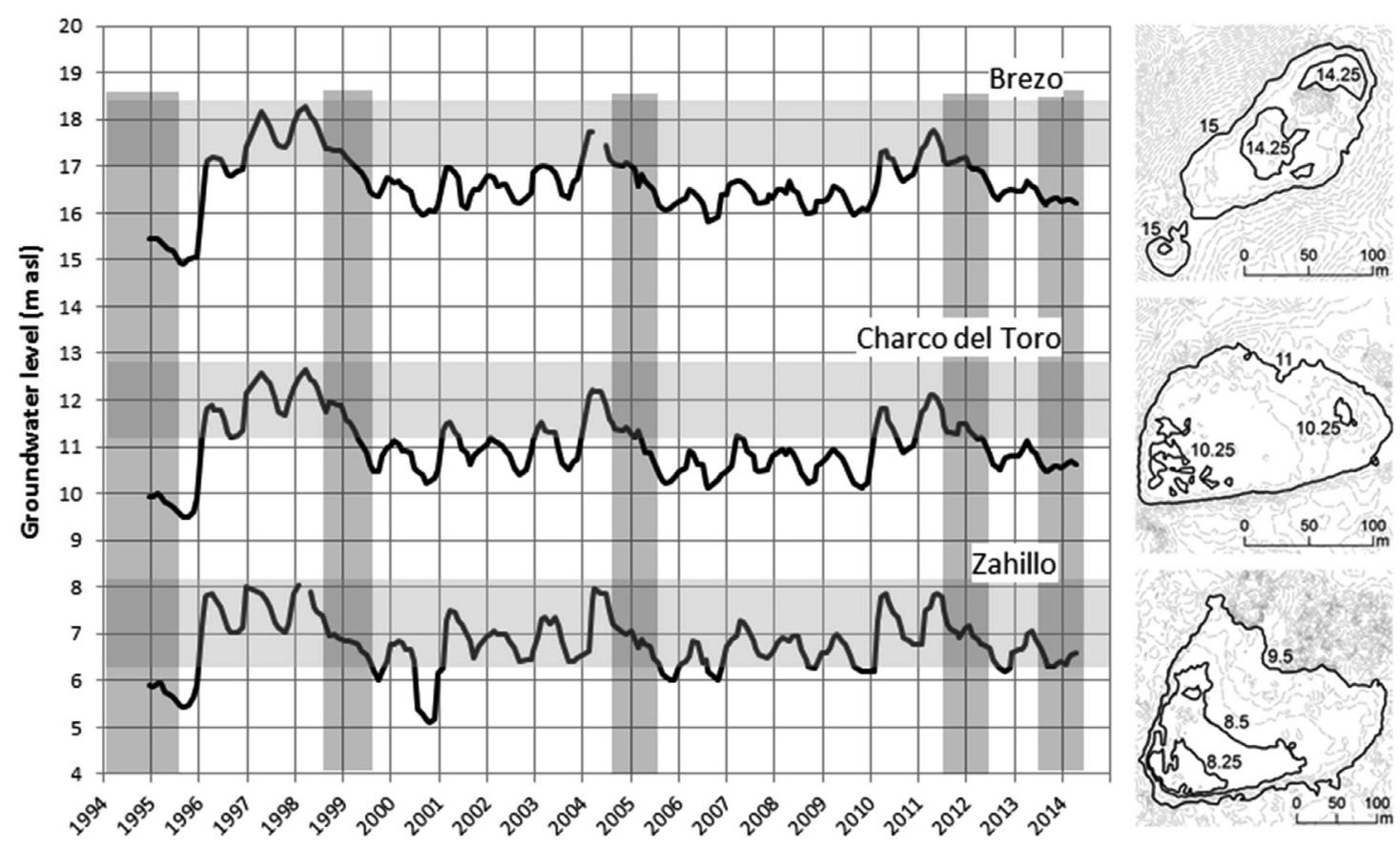

Figure 3. Variation in the height of groundwater above sea level (asl) recorded by piezometers located close to Brezo, Charco del Toro and Zahillo ponds. The grey horizontal bars indicate the approximate level from which the inundated pond surface was observed and grey vertical bars indicate dry years. Isolines for the basins of each pond are shown on the right. Variación de los niveles piezométricos registrados junto a las lagunas del Brezo, Charco del Toro y Zahillo. La barra horizontal gris indica aproximadamente el nivel a partir del cual se observó la superficie de cada laguna inundada. Se muestra también las curvas de nivel de las cubetas de cada laguna. 
mante et al., 2009). For MSS images we followed the same approach using as reference one Landsat 4 TM summer scene acquired in 1985 by both sensors MSS and TM aboard of the same platform. RMS error in this case was independently estimated in $23.01 \mathrm{~m}$.

The best semiautomatic method was determined after discriminating inundation levels according to ground-truth data and final inundation masks were produced for every image by merging low inundated and dry soil categories with wet and fully flooded pixels. Landsat TM and $\mathrm{ETM}+$ band 5 are the least sensitive to the sediment load and is considered as the best indicator of flooding in shallow, turbid, or with abundant aquatic vegetation waters (Lee et al., 2001). To discriminate land covered by water, we used a simple threshold method on the TM band 5 $(1.55-1.75 \mu \mathrm{m})$ reflectivity and MSS band 4 (0.8$1.1 \mu \mathrm{m})$ reflectivity, that enabled to detect different inundation levels (Bustamante et al., 2005). We classify as inundated pixels those with band 5 reflectivity <0.145 (Díaz-Delgado et al., 2006).

We overlaid on a GIS the ponds limits (Gómez-Rodriguez et al., 2011) with an external buffer of $45 \mathrm{~m}$ and extracted for each inundation mask, the number of pixels flooded for each pond. We eliminated any images in which we had little confidence (mainly because of the presence of cloud cover or cloud shadows, which especially affected data availability for very rainy years or other radiometric problems). Due to technical problems, we had no data for the summer of 2001 and 2003.

Using TM Landsat images ( 1 pixel $=30 \times$ $30 \mathrm{~m}$ ), we were able to reconstruct pond inundation area from 1984 to 2014. However, because pressure on the aquifer has intensified since Matalascañas was built, in 1970, we wanted to extend our study period further back. Therefore, for the largest and most permanent pond (Santa Olalla), we also used Landsat MSS images, which provided additional data for the period from 1975 to 1993 . These images had lower resolution levels $(1$ pixel $=60 \times 60 \mathrm{~m})$ and thus could not be used for the other, smaller ponds.

In each of the Landsat images, we estimated the relative inundation levels of each pond (here- after inundation levels) as a percentage of flooded area in each image in relation to the maximum inundated area attained by the pond over the entire study period. We determined the number of years in which the ponds dried out,reaching $0 \%$ inundation levels in any month of the year. Ponds that regularly dried out in the summer (more than $40 \%$ of the years) were classified as seasonal; those that dried up less frequently were classified as semipermanent; and Santa Olalla, which only dried up in 1995, was classified as a permanent pond. We analyzed the relationship between summer inundation levels and annual rainfall. For the seasonal ponds, we used June values, in order to avoid $0 \%$ inundation levels (except those 0 values recorded in June). For semipermanent and permanent ponds, we used September values.

The annual hydrological cycle is considered to run from October 1 to September 30 (of the following year). Annual rainfall data were recorded at a meteorological station located $3 \mathrm{~km}$ from the ponds that provided data from 1978-79 to 2013-2014. The earliest data (1970-71 to 1977-78) were obtained from CGS (2008). Average annual rainfall in this area is $547.5 \mathrm{~mm}$ (for the period 1970-71 to 2013-2014). We classified the years in our study according to the annual rainfall levels. In average years, rainfall ranged from 450 to $650 \mathrm{~mm}$; in dry years, it was less than $450 \mathrm{~mm}$; and in rainy years, it was greater than $650 \mathrm{~mm}$.

To further determine whether particular ponds dried up, we used data on variation in water table levels that were recorded using piezometers located close to the ponds. These data were provided by the Confederación Hidrográfica del Guadalquivir, an institution that monitors groundwater levels using a network of 195 piezometers spread across the whole protected area (CGS, 2008). Piezometer data were available for the period from 1995 to 2014 . We used these data to assess variation in groundwater levels in the three ponds closest to Matalascañas. Piezometers are located a few meters away from the pond basin associated with these three ponds. Their measurements on groundwater depth have been approximately related to the bottom of the pond basin, based in our direct measures on pond 
water levels recorded in periods coincident with piezometer records. The batimetry of the pond basins was obtained on a Digital Model Terrain (LIDAR) obtained when they were dry with $2 \mathrm{~m}$ pixel and altimetry accuracy of $0.15 \mathrm{~m}$.

To assess pond inundation trends across the study period, we plotted the relationship between summer inundation levels and annual rainfall. We grouped our data into four periods, which covered approximately a decade of time each: 19751984 (only for the permanent pond Santa Olalla); 1985-1994 (all ponds); 1995-2004 (all ponds) and 2005-2014 (all ponds). The first and second periods include the first years after Matalascañas was founded; during the third and fourth ones the village had a high increase in buildings, when its urban area was doubled and included the construction of a golf course in 2000 (see figure
$\mathrm{S} 1$, available in the supplementary information at www.limnetica.net/net), The general trend for each time period is shown by a regression line. Because severe droughts affected aquifer dynamics, in a manner similar to artificial perturbations (see Custodio \& Palancar, 1995), we excluded years when rainfall fell below $300 \mathrm{~mm}$ when carrying out the regressions.

\section{RESULTS}

\section{Variation in annual rainfall}

Annual rainfall was highly variable throughout the study period (Fig. 2). Average annual rainfall was $547.5 \mathrm{~mm}$, however, dry years with less than $400 \mathrm{~mm}$ and very rainy years with more

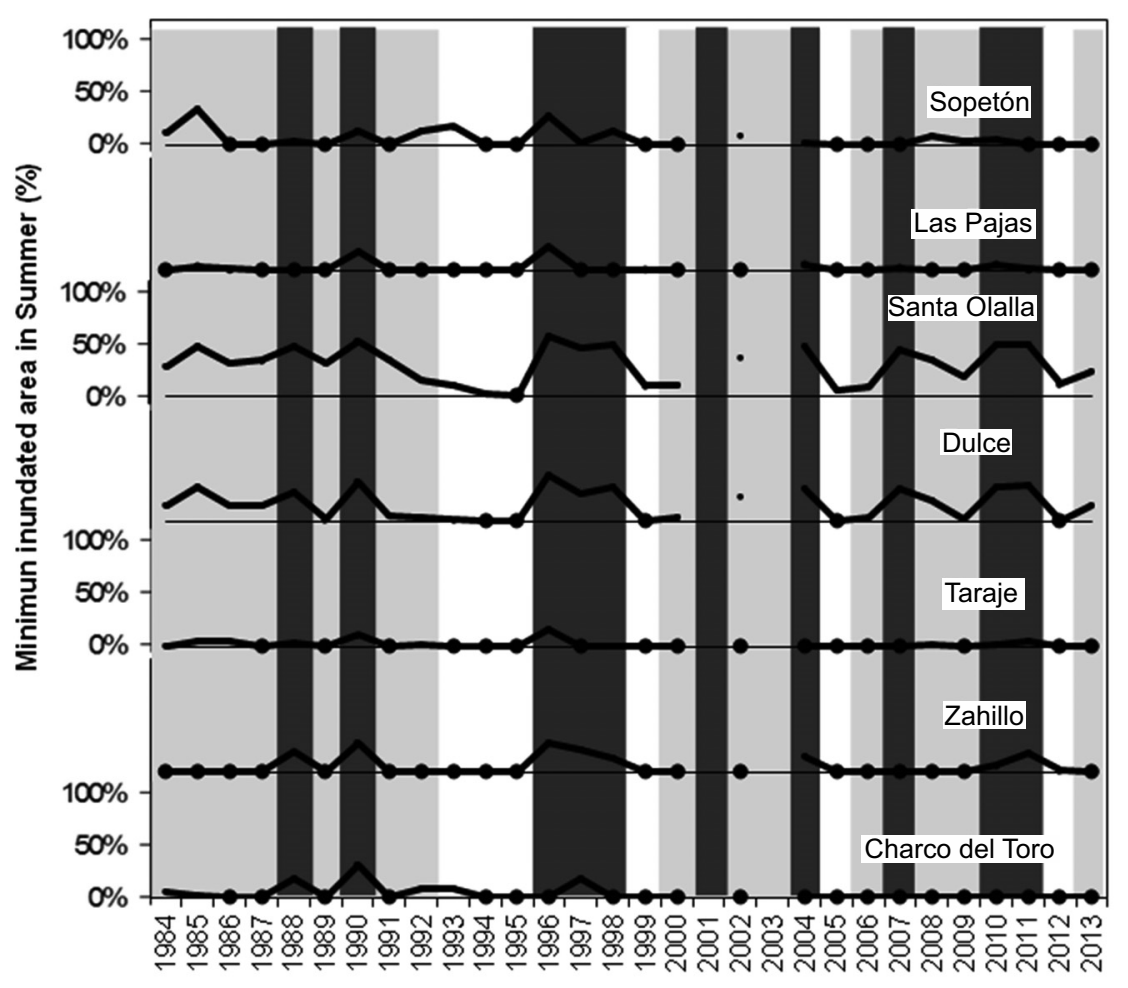

Figure 4. Minimum inundation recorded in summers in the study ponds, using Landsat Images from 1984 to 2014 . The large filled circles indicate years in which each pond dried up in the summer. The ponds are shown in similar order as their distance to Matalascañas. Vertical bars: White: dry years; clear gray: average years; dark gray: very rainy years. Mínima inundación registrada durante el verano en la lagunas estudiadas, estimada mediante imágenes Landsat entre los años 1985 a 2014. Los círculos grandes negros indican los años en que las lagunas se secaron en verano. Las lagunas se muestran en el mismo orden que presenta la distancia de cada una a Matalascañas. Bandas verticales: blancas: años secos; gris claro: años de precipitación media; gris oscuro: años muy lluviosos. 
than $700 \mathrm{~mm}$ were not infrequent. There were two prolonged periods of drought. The first one (1979-80 to 1982-83) included consecutive dry years that alternated with and were followed by normal years. The second one (1991-92 to 199495) included three consecutive dry years that followed two years of below-average rainfall. These droughts had a major impact on pond hydrology, because, in the last summers of both periods, all ponds in the area went dry, with the exception of Santa Olalla, which only dried up in 1995. Since the last drought, some isolated dry years have occurred, among which 2005 was exceptionally dry (rainfall $=169.8 \mathrm{~mm}$ ). Very rainy years are particularly important, as rainfall is the main source by which the aquifer is recharged. The greatest amount of rain occurred from 1995-96 to 199798 , and there were two similarly rainy periods from 1976-77 to 1977-78 and more recently from 2009-10 to 2010-2011.

\section{Dry ponds}

The first sign that the study area is being affected by groundwater abstractions is pond desiccation; ponds are then consequently invaded by terrestrial vegetation. At present, two of the ponds closest to Matalascañas no longer regularly flood. The piezometric data reveal that only in very rainy years water level raised over the
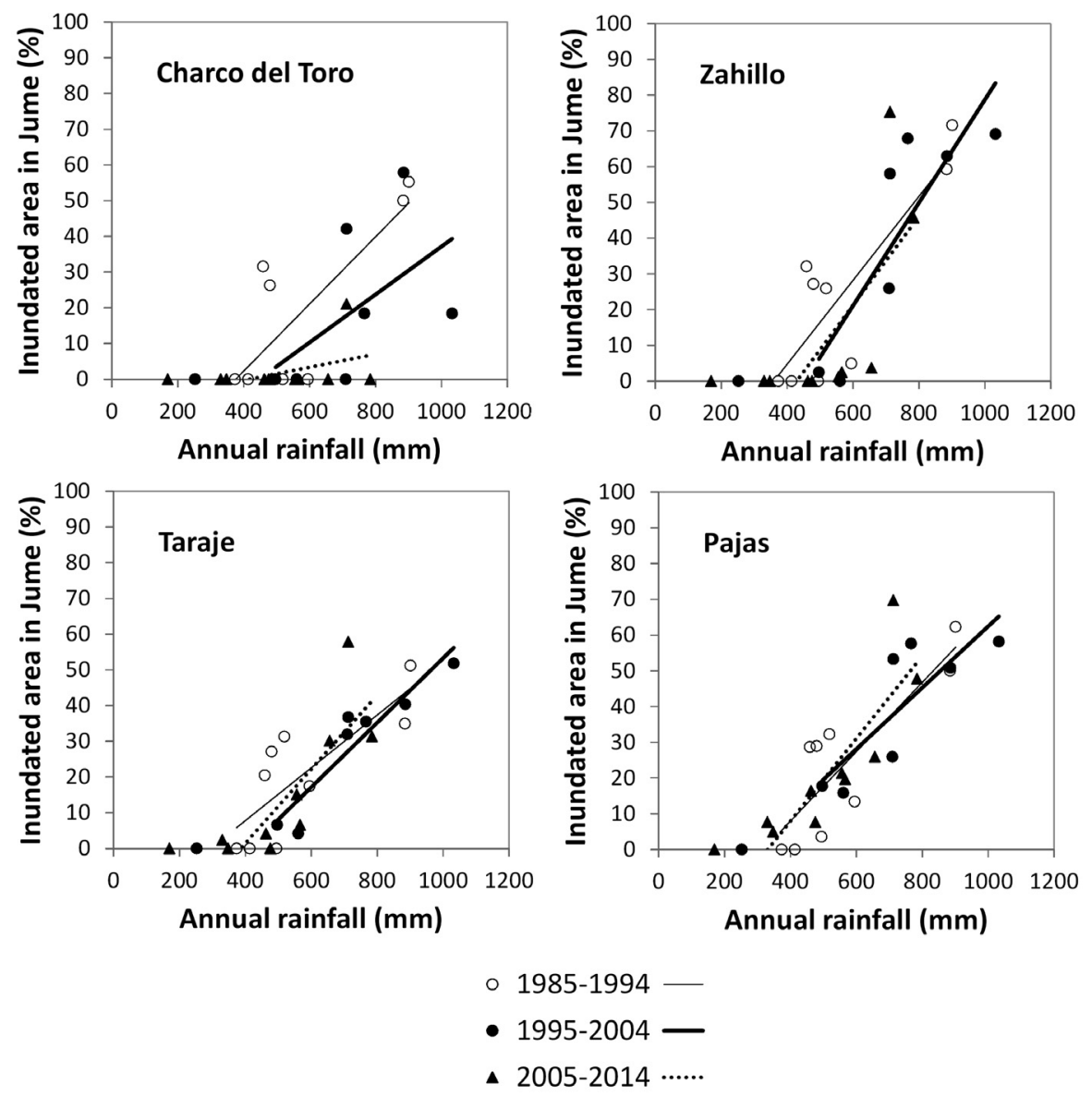

Figure 5. Percentages of inundated area of seasonal ponds recorded in June in relation to the annual rainfall. Trends for each period are indicated using regression lines. Calculations of regression lines did not include years with annual rainfall values below $300 \mathrm{~mm}$. Porcentaje del área inundada registrada en Junio para las lagunas estacionales en relación a la precipitación anual. Las tendencias se indican mediante la línea de regresión, que se ha calculado excluyendo valores de precipitación anual inferiores a 300 mm. 
ground (Fig. 3), then small ponds of short duration are formed on their basins. The first pond to dry up, Brezo, is the one with highest altitude and is found close to the pumping stations. It was first reported to dry up in 1976 (Hollis et al., 1989; Valverde, 2004). The second pond, Charco del Toro, is an extensive seasonal pond that was first reported to have dried out in 1998 (Coleto, 2003). It did partially flood during the two very rainy years: 2002-03 and 2003-2004. However, since the very dry year 2004-05, it has demonstrated only a minimal amount of flooding in particularly rainy years (2009-10 and 2010-11). Therefore, we currently consider this pond to be desiccated. A third peridune pond, Zahillo, is also showing signs of desiccation; it is third in elevation and distance to the pumps, after Brezo and Charco del Toro. Over the study period, its maximum inundation area was 7.3 ha, but in recent years (since 1999), it formed two smaller ponds, that are only connected in very rainy years or for short periods after heavy rains (personal observations).

\section{Pond seasonality}

Using the minimum inundation area of each pond prior to each new hydrological cycle, we were able to determine the number of years in which each pond dried up (Fig. 4). Seasonal ponds were those that usually dried up in summer, although they remained somewhat inundated in the summers of very rainy years (rainfall $>700 \mathrm{~mm}$ :
1988, 1990, 1996, 2004, 2010 and 2011). However, they nonetheless dried up in very rainy years if the accumulated rainfall of the two previous years did not exceed $1300 \mathrm{~mm}$ (or $1820 \mathrm{~mm}$ in the three previous years). This group includes ponds found at the highest elevations and closest to Matalascañas (Charco del Toro, Zahillo and Taraje), as well as the very shallow Las Pajas, a pond located farther away and at a lower elevation. The other three ponds in our study were considered to be permanent by some authors (Valverde, 1958; Sacks et al., 1992, Toja 2006), although two of them (Dulce and Sopetón) dried up during the summer in the driest years (rainfall $<450 \mathrm{~mm}$ ), and even Sopetón dried up in 2013, a year with $550 \mathrm{~mm}$ of rainfall. At present, only the largest pond -Santa Olalla- should be considered to be permanent, although even it has reached very low water levels during periods of severe drought, such as in 1980-83 and in 1991-95, and it dried up in the summer of 1995. Landsat images (MSS Landsat) did not reveal inundated pixels in 1983, but locals insisted that the pond only dried up in 1995.

\section{Relationship between summer inundation areas and annual rainfall}

\section{Seasonal ponds}

For the seasonal ponds (Charco del Toro, Zahillo, Taraje, Las Pajas), we studied the relation-
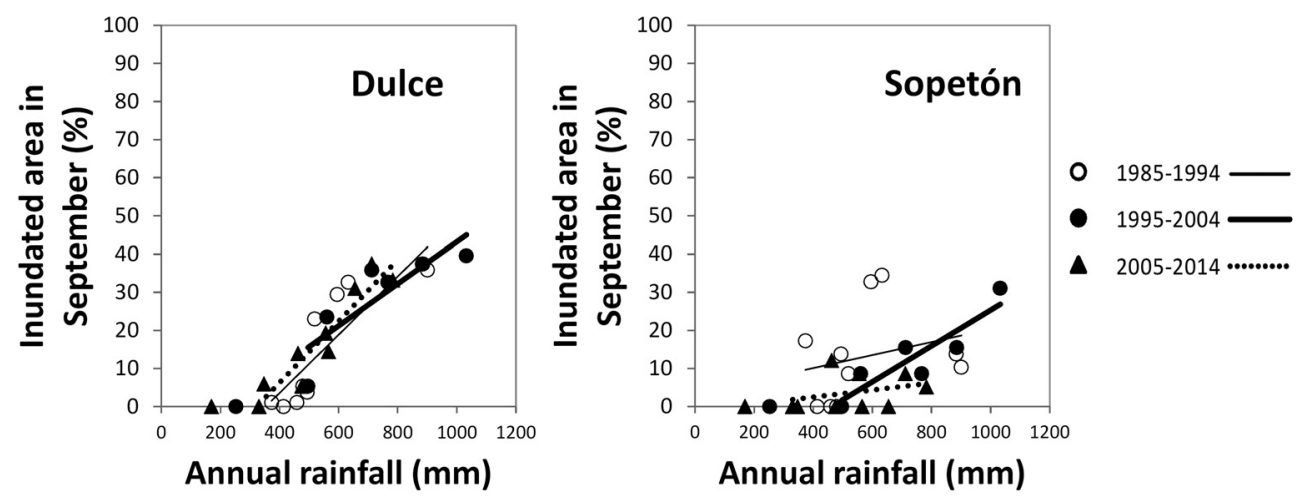

Figure 6. Percentage of inundated area of the semipermanent ponds (Dulce and Sopetón) estimated in September in relation to annual rainfall. Trends for each period are indicated using regression lines. Porcentaje del área inundada en septiembre en las lagunas semipermanentes (Dulce y Sopetón). Las tendencia de cada década se indican mediante la línea de regresión. 
ship between annual rainfall and June inundation levels (Fig. 5), because these ponds are usually dry in July or August. Annual rainfall was positively correlated with June inundation areas, which were higher in rainier years (Fig. 5). Looking at temporal trends, we observed that, during the first decade (1985-1995), the highest annual rainfall value at which Charco del Toro went dry in June was $632.9 \mathrm{~mm}$; in contrast, in the second (1995-2004) and third decades, it went dry at higher annual rainfall values (1995-2005: $709 \mathrm{~mm}$; 2005-14: $784 \mathrm{~mm}$ ). Even though annual rainfall values were similar $(400-700 \mathrm{~mm})$, for the three periods, Zahillo and Taraje remained flooded for longer in 1985-1995 than in 19952005 or 2005-14. However, Taraje did contain some water in June in the dry years of the last study decade. Las Pajas only dried up in June in the first and second decades.

\section{Semipermanent ponds}

For Dulce and Sopetón, we have analyzed the percentages of inundation levels in September, as it is the month during which the ponds become desiccated in very dry years.
Both ponds showed a general tendency to have higher inundation levels in rainier years, but the trend was more pronounced in more recent decades. As in the case of the seasonal ponds, during the last two study decades, these ponds dried up even in years with above-average rainfall while it did not occur in the earliest period (Fig. 6).

\section{The permanent pond}

At present, Santa Olalla is the only pond that we can classify as permanent. Variation in September inundation levels can be seen in figure 7; one caveat is that the data prior to 1985 come from MSS Landsat images and are therefore of lower resolution. Inundation levels were lowest in 1983 and 1995, in the opinion of locals, the pond only dried out in 1995, the last year of a severe fouryear drought. Early on, inundated levels were not related to annual rainfall, in a period in which groundwater abstractions appears to have had a minimal impact on pond flooding. However, for 1985-95, a positive trend can be seen and the two variables demonstrate a significantly positive relationship for the last two decades (Fig. 7).

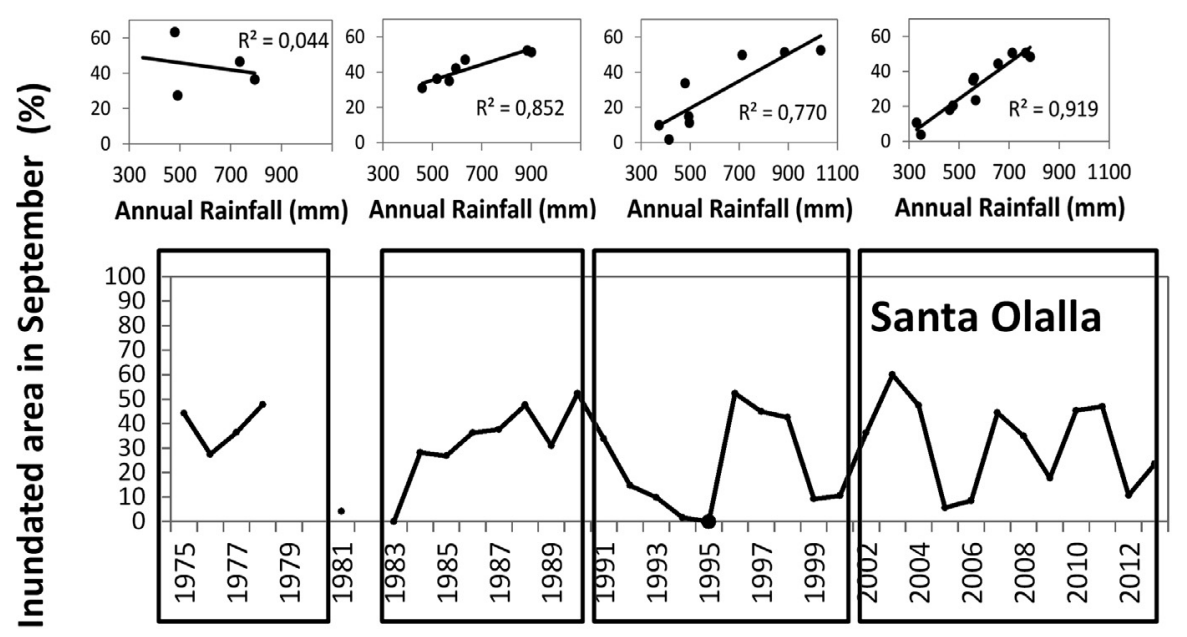

Figure 7. Variation in percentage of inundated area recorded in September in the permanent pond, Santa Olalla, from 1975 to 2014. The relationship between percentage of inundated area and annual rainfall is shown in the graph in the upper half of the figure for the time periods encosed in the graph underneath. Trends are shown in the upper graphs using regression lines (from 1975-1984, data were recorded using MSS Landsat images). Variación del porcentaje del area inundada en Septiembre en la laguna permanente, Santa Olalla, desde 1975 hasta 2014. En la parte superior se indica la relación entre el porcentaje de área inundada y la precipitación anual para el periodo enmarcado en la gráfica inferior. (los datos del periodo 1975-1984 se estimaron sobre imágenes Landsat MSS). 
Indeed, overall Santa Olalla summer inundation levels were not singnificantly correlated with annual rainfall in the first two study decades (19751994: $R^{2}=0.392, p=0.029$ ), but a significant correlation was observed in the last two (19952014: $R^{2}=0.901, p<0.0005$ ).

In temporary pond networks, wetlands recover from the dry summer phase after the rains that fall during the subsequent annual cycle. To assess Santa Olalla's capacity to recover after dry years, we examined summer inundation levels in average-rainfall years that followed dry years. These particular conditions occurred four times during our study period. The flooding levels in these years are shown in figure 8. We found that the pond's ability to recover declined dramatically over time. Although we do not have a valid Landsat image with which to estimate the inundation level in the dry year 1983, we do know from field observations that the level was lower than in $1981(<4.18 \%)$. In 1984, after $568 \mathrm{~mm}$ of rainfall, the inundation level was $35.1 \%$. In contrast, in the other paired years, summer inundation of the pond was higher in the corresponding dry years, but the increase in inundation levels in the following years were lower than in 1984. In 2000, after a year of 497 $\mathrm{mm}$ in rainfall, the inundation level was $1.9 \%$; it was $11 \%$ in 2006 and $12.8 \%$ in 2012 (Table 2).

\section{DISCUSSION}

In this study we assessed the variation in inundation of the most important ponds in Doñana using remote sensing. Piezometric levels have revealed a severe decline in groundwater levels in certain areas of the park (Custodio et al., 2009) and, more than 20 years ago, predictive models alerted that this could result in decreased pond inundation levels or even the drying up of numerous temporary ponds (Vela et al., 1991; Lozano, 2004; Manzano \& Custodio, 2006). However, there are no specific data on the variations in water level, extension or inundation regimes of the water bodies that can be used to evaluate the consequences of the detected decline in groundwater levels. Since most aquatic habitats in Doñana are temporary and their natural dynamics include a dry phase during the summer, the absence of inundation in occasional years has not still alerted managers. The frequent alternation of dry and
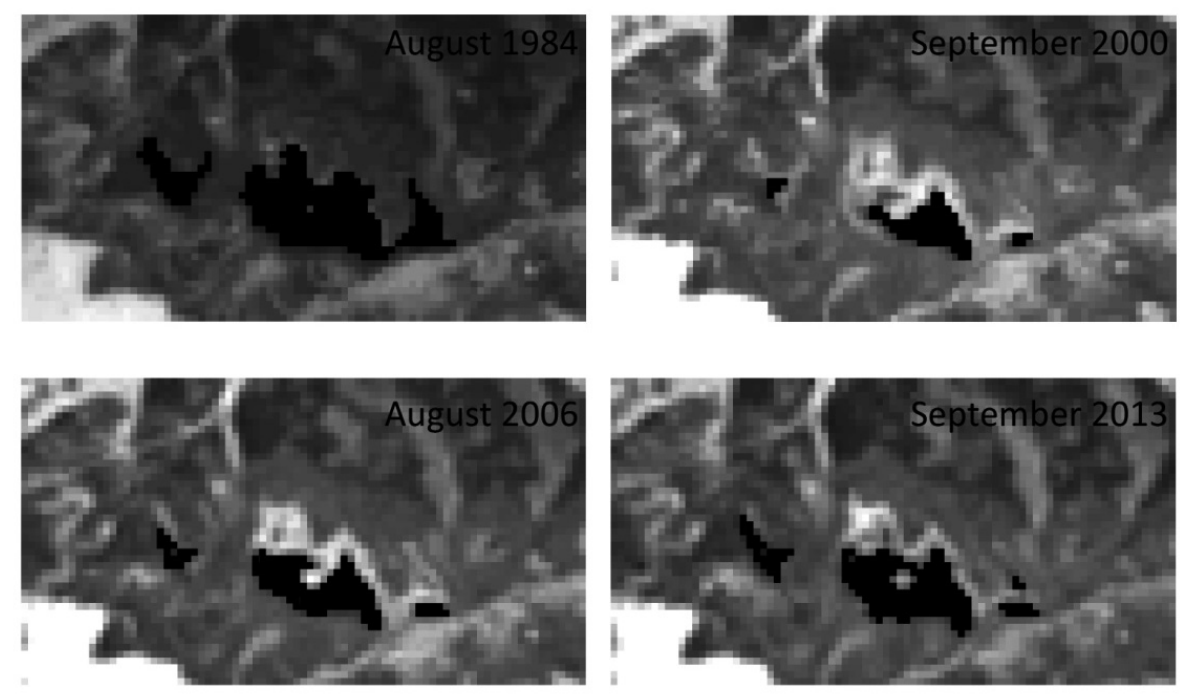

Figure 8. Estimated inundated area for Santa Olalla pond overlaid on Landsat images recorded in August or September of four years of average annual rainfall following dry years. Estima del area inundada en la laguna de Santa Olalla sobrepuesta sobre las correspondientes imágenes Landsat, registradas en agosto o septiembre de cuatro años de precipitación anual media que siguieron a años secos. 
very rainy years which produce large fluctuations in water levels and inundation is an additional disconcerting factor that makes it difficult to assess the conservation status of this pond network. This is likely the reason why, in spite of the knowledge of the gradual decrease in groundwater levels which has taken place over the last few decades, as well as the recommendations that the park has received since 1988 (Hollis et al., 1989; Comisión Internacional de Expertos, 1992; Custodio et al., 2009), the problem is still unresolved, and no actions have been taken to avoid a greater deterioration of the whole system.

Remote sensing is a useful tool for assessing historic variation in inundated areas (Revenga et $a l ., 2005)$, and it has also been proven to be useful in the assessment of variation in hydroperiod of temporary ponds in the central area of the park (Gómez-Rodriguez et al., 2010). The latter study found a trend of shorter annual periods of pond inundation. However, this trend did not correspond with the trends observed for annual rainfall or for total flooded area for the same time period, suggesting that shorter annual hydroperiods were independent of the natural flooding regime of the ponds and were probably related to groundwater dynamics (Gómez-Rodríguez et al., 2010).

In this study, we have focused on the ponds of greatest size and longest hydroperiod in the park, since it is easier to detect a shortening of the hydroperiod or inundation levels in these ponds, especially in those that were considered permanent. We analyzed the frequency of years in which these ponds dried out (most of the other ponds dry out every summer). Ponds in
Doñana are mainly fed by groundwater, which in this area is mainly recharged by rainfall (Sacks et al., 1992, Coleto, 2003, Serrano et al., 2006; Custodio et al., 2009); therefore, a positive relationship between the variation in pond inundation level and rainfall is expected. Our results confirm this relationship through the assessment of the variation of the inundation in the area in summer. In years with high rainfall, the water table is higher and ponds retain surface water longer than in dry years, when the water table is lower (Coleto, 2003). In general, over our study period, we detected an increase in the number of years that the ponds were dry, as well as lower levels of pond inundation, even including pond desiccation, over the last two decades. However, our data on seasonal and semipermanent ponds are not conclusive, as they cover a period (1985-2014) in which the system was already influenced by significant groundwater abstractions. Moreover, it is probable that the inclusion of one of the most significant drought periods in the first decade of our study period, when maximum desiccation in the area was detected, contributed to the strong relationship with rainfall in this decade. Since the effects of pumping perturbations to the aquifer are similar to those produced by extreme droughts (Custodio \& Palancar, 1995; Custodio et al., 2009), we have eliminated data for very dry years from our analyses. However, the low levels reached during prolonged periods of those dry years also influenced the trends detected, since in post-dry years the system required higher recharges to return to normal pond inundation

Table 2. Percentage of inundated area of Santa Olalla Pond recorded in September of dry years and in the year following (if it was a year of average rainfall). The total increase in inundated area experienced in the second year and rainfall amounts for each year are also indicated. Porcentaje del área inundada en Septiembre de la laguna de Santa Olalla en años secos y en el año siguiente (cuando éste se caracterizaba por un año de precipitaciones medias). Se indica también el incremento del área inundada que se produce el segundo año en la laguna y la cantidad de precipitaciones de cada año.

\begin{tabular}{ccccccc}
\hline & \multicolumn{2}{c}{ Dry year } & & \multicolumn{3}{c}{ Following average year } \\
\cline { 2 - 4 } Year & $\begin{array}{c}\text { Rainfall in the } \\
\text { dry year (mm) }\end{array}$ & $\begin{array}{c}\text { \% inundated area } \\
\text { in the dry year }\end{array}$ & Year & $\begin{array}{c}\text { Rainfall in the next } \\
\text { year }(\mathrm{mm})\end{array}$ & $\begin{array}{c}\text { \% inundated area } \\
\text { in the next year }\end{array}$ & $\begin{array}{c}\text { Increase in the } \\
\text { second year }(\%)\end{array}$ \\
\hline $1982-1983$ & 276.2 & $<4.18$ & $1983-1984$ & 568.4 & 35.1 & 11.19 \\
$1998-1999$ & 252.7 & 9.25 & $1999-2000$ & 496.7 & 18.06 & 1.94 \\
$2004-2005$ & 169.8 & 7.02 & $2005-2006$ & 462.8 & 23.58 & 11.04 \\
$2011-2012$ & 330.4 & 10.75 & $2012-2013$ & 566.1 & 12.84 \\
\hline
\end{tabular}


levels. Incorporating Landsat MSS images data, we were able to assess the inundation dynamics of the permanent pond for an initial older period in which we could assume that this area would have a lower experienced less impact from groundwater abstraction, though it would already have experienced human impact. During this period, significant declines in groundwater were already occurring in the northern area of the park due to extensive agriculture irrigation (CGS, 2008; Custodio et al., 2009). Matalascañas still had a low building density and its water supply would have had a considerably lower impact on the ponds than in more recent years (though desiccation of the first nearby pond had already occurred). Although analysis of the permanent pond, Santa Olalla, includes two long periods of dry years in which it occasionally reached extreme desiccation values, the variation in inundation, demonstrates a change in the pond's dynamics from approximately constant levels in the period from 1974-75 to 1993-94 to a higher dependency on the annual rainfall during the last two decades. In fact, the variation represents a change from a large pond that was a discharge area of the aquifer all year round (Sacks et al., 1992; Coleto, 2003), to a recharging area that has been reaching very low levels of inundation in the summers of recent years (see a comparison of the low summer inundation in Santa Olalla in the last years versus summer inundation in previous years in figure S2 (available in the supplementary information at www.limnetica.net/net). Similar changes were observed in 1998-99 when this pond reached very low levels of inundation (Lozano, 2004). Moreover, the pond's capacity to return to normal inundation levels following dry years has further diminished since 2000, when a golf course was opened at the nearby tourist resort. We can not treat Matalascañas and its golf course as the only factors responsible for the current malfunctioning of the chain of peridune ponds in Doñana, but their water supply and proximity to the ponds represent an additional negative impact which contributes to the general decline of the aquifer as reported by piezometers monitoring (CGS 2008, Custodio et $a l ., 2009)$. The decline in groundwater in certain areas of the park has resulted in depth values as low as $18 \mathrm{~m}$ deep, while in the area of Matalacañas pumping stations the decline reached $5 \mathrm{~m}$ depth (CGS, 2008). Although in peridune ponds groundwater does not presently reaches such low declines, they are reaching inundation levels similar to the years in which the maximum desiccation occurred, after the long drought in 1995. The maximum depth of Santa Olalla is about $3.5 \mathrm{~m}$, and depth in summer of wet years was about $2.5 \mathrm{~m}$ (Coleto, 2003). Therefore, a decline of 2-3 $\mathrm{m}$ of groundwater in this area of the park could result in the complete desiccation of the peridune ponds, and, consequently, of the whole pond network in the park.

The question that concerns us at this time is the following: Should we consider Santa Olalla as a permanent or a temporary pond?

Temporary ponds are important for biodiversity conservation because they provide aquatic habitats for very specialized flora and fauna species. These are aquatic species that do not survive in permanent waters but are adapted to resist dry phases by means of different strategies, such as development of resistance phases, organisms with complex cycles that spend aquatic and terrestrial phases, or dispersal or migration to other aquatic habitats that are used as summer refuges (Wiggins et al., 1980). For a temporary pond network, the existence of permanent waters contributes to an increase in the stability of the system by supporting the summer refuges needed to preserve animal richness (mainly of dispersant macroinvertebrates). In Doñana, presently, the only permanent natural pond is Santa Olalla, although there are also around 200 small-sized ponds that have been artificially deepened in order to provide water for wild fauna and cattle. Nowadays, these semi-artificial ponds are the only summer habitats of dytiscids and hemipters (Florencio et al., 2014a), the breeding habitats of odonata with long larval periods, and of several species of amphibians (Díaz-Paniagua et al., 2005), as well as the only sites where various threatened aquatic plants still persist (Florencio et al., 2014b). In fact, given the low inundation of the peridune ponds that has been detected in recent years, conservation of the aquatic biodi- 
versity of Doñana ponds needs to be sustained by these semi-artificial ponds. These ponds require continuous management to maintain adequate conditions. They face significant pressure from wild mammals and cattle, as they are the only drinking available ponds in dry periods.

Doñana temporary ponds form the most important temporary pond network in Europe (Díaz-Paniagua et al., 2010), where these habitats have priority conservation considerations (CODE 3170 of EU Habitats Directive). Groundwater overexploitation is currently threatening this network that sustains a high number of threatened species of flora and fauna, and management measures should be taken immediately to correct the present deterioration and to prevent the significant loss of biodiversity that the desiccation of this pond network would represent.

\section{CONCLUSIONS}

Using information from Landsat images, we found that, over the last four decades, Doñana's biggest ponds have tended to have lower inundation levels. We can confirm that the two ponds located closest to the pumping station of the nearby beach resort are currently dry. All the park's ponds have become more dependent on annual rainfall, even the most permanent ones whose inundation levels were seemingly unaffected by annual rainfall 30-40 years ago. Overall, these results indicate that inundation levels have decreased and, as predicted by previous studies, pond desiccation has increased, which shows the general decline in groundwater levels in this protected area.

\section{ACKNOWLEDGEMENTS}

This study was funded by the Spanish Ministry of Agriculture, food and Environment (project 158/2010). We thank the Remote Sensing \& GIS Laboratory (LAST-EBD) from Doñana Biological Station for providing and processing Landsat images, and Hector Garrido for aerial photographs provided for Appendix.

\section{REFERENCES}

BUSTAMANTE, J., R. DÍAZ-DELGADO \& D. ARAGONÉS. 2005. Determinación de las características de masas de aguas someras en las marismas de Doñana mediante teledetección. Revista de Teledetección, 24: 107-111.

BUSTAMANTE, J., F. PACIOS, R. DÍAZ-DELGADO \& D. ARAGONÉS. 2009. Predictive models of turbidity and water depth in the Doñana marshes using Landsat TM and ETM+ images. Journal of Environmental Management, 90: 2219-2225.

CGS (COMPAÑÍA GENERAL DE SONDEOS). 2008. Situación Hidrodinámica actual de la Unidad Hidrogeológica Almonte-Marismas. Año hidrológico 2004-2008. Confederación Hidrográfica del Guadalquivir. Ministerio de Medio ambiente. Dirección General del Agua.

COLETO, I. 2003. Funciones hidrológicas y biogeoquímicas de las formacionespalustres hipogénicas de los mantos eólicos de El Abalario-Doñana (Huelva). Tesis doctoral, Universidad Autónoma de Madrid.

COMISIÓN INTERNACIONAL DE EXPERTOS. 1992. Dictamen sobre estrategias para el desarrollo socioeconómico sostenible del Entorno de Doñana. Junta de Andalucía. Sevilla.

CUSTODIO, E. \& M. PALANCAR. 1995. Las aguas subterráneas en Doñana. Revista de Obras Públicas, Madrid, 142 (3340): 31-53.

CUSTODIO,E, M. MANZANO \& C. MONTES. 2009. Las aguas subterráneas en Doñana-Aspectos ecológicos y sociales, Agencia Andaluza del Agua, Consejería de Medio Ambiente.

DÍAZ-DELGADO, R., J. BUSTAMANTE, D. ARAGONÉS \& F. PACIOS. 2006. Determining water body characteristics of Doñana shallow marshes through remote sensing. Proceedings of the 2006 IEEE International Geoscience \& Remote Sensing Symposium \& $27^{\text {th }}$ Canadian Symposium on Remote Sensing. July-4 August 2006. Denver, Colorado, USA: 3662-3664.

DÍAZ-PANIAGUA,C., C. GÓMEZ RODRÍGUEZ, A. PORTHEAULT \& W. DE VRIES. 2005. Los anfibios de Doñana. Serie Técnica. Ministerio Medio Ambiente, OAPN, Madrid.

DÍAZ-PANIAGUA, C., R. FERNÁNDEZ-ZAMUDIO, M. FLORENCIO, P. GARCÍA-MURILLO, C. GÓMEZ-RODRÍGUEZ, A. PORTHEAULT , L. SERRANO \& P. SILJESTROM. 2010. Temporary ponds from the Doñana national park: a 
system of natural habitats for the preservation of aquatic flora and fauna. Limnetica, 29: 41-58.

FLORENCIO, M., C. DÍAZ-PANIAGUA, C. GÓMEZ-RODRÍGUEZ \& L. SERRANO. 2014a. Biodiversity patterns in a macroinvertebrate community of a temporary pond network. Insect Conservation and Diversity, 4(7): 4-21.

FLORENCIO, M., L. SERRANO, P. SILJESTROM, R. FERNANDEZ-ZAMUDIO, P. GARCIA-MURILLO \& C. DÍAZ-PANIAGUA. 2014 b. The influence of geomorphology on the composition of aquatic flora and fauna within a temporary pond network. Limnetica, 33(2): 327-339

GARCÍA-NOVO, F. (coordinador). 1994. Informe sobre el estado de la Reserva de la Biosfera de Doñana. Comité Español del Programa MAB de la UNESCO.

GARCÍA-NOVO,F. \& C. MARÍN. 2006. Doñana, Water and Biosphere. Confederación Hidrográfica del Guadalquivir, Ministerio Medio Ambiente. Madrid.

GÓMEZ-RODRÍGUEZ,C., J. BUSTAMANTE \& C. DÍAZ-PANIAGUA. 2010. Evidence of hydroperiod shortening in a preserved system of temporary ponds. Remote sensing, 2: 1439-1462.

GÓMEZ-RODRIGUEZ, C., C. DÍAZ-PANIAGUA \& J. BUSTAMANTE. 2011. Cartografía de Lagunas temporales del Parque Nacional de Doñana. Agencia Andaluza del Agua. Consejería Medio Ambiente. Junta de Andalucía, Sevilla. (LIBRO_CD).

HOLLIS, T., P. HEURTEAUX \& J. MERCER. 1989. Misión WWF/IUCN/ADENA al Parque Nacional de Doñana, 18-22 de Noviembre 1988. Las consecuencias de la Extracción de aguas subterráneas para el futuro alargo plazo del Parque Nacional de Doñana. Proyecto subvencionado por Worl Wide Fund for nature (International).

JUNTA DE ANDALUCÍA. 2003. Ortofotografía digital de Andalucía. Color photogrametric flight 1:60.000 (1998-1999).

LOZANO, E. 2004. Las aguas subterráneas en los Cotos de Doñana y su relación con las lagunas. Tesis doctoral, ETSICCP, Universidad Politécnica de Cataluña, Barcelona.

LLAMAS, M. R. \& A. GARRIDO. 2007. Lessons from intensive groundwater use in Spain: Economic and Social benefits and conflicts. In: The agricultural groundwater revolution: Opportunities and threats to development. M. Giordano \& K. G. Villholth (eds.): 266-295. CAB International Publishing, Wallingford, UK.
MANZANO, M. \& E. CUSTODIO. 2006. The Doñana aquifer and its relations with the natural environment. In: Doñana, Water and Biosphere. F. García Novo \& C. Marín Cabrera (eds.): 141150 Spanish Ministry of the Environment, Madrid, Spain.

MANZANO, M., E. Custodio, H. HIGUERA, R. PUIG \& A. SOLER. 2001. Influencia de la gestión del acuífero sobre los humedales del manto eólico de Doñana. Boletín Geológico y Minero, 120(3): 377-392.

MUÑOZ-REINOSO, J. C. 2001. Vegetation changes and groundwater abstraction in SW Doñana, Spain. Journal of Hydrology, 242: 197-209.

PONS, X. 2004. MiraMon. Sistema de Información Geográfica y software de Teledetección. Centre de Recerca Ecològica i Aplicacions Forestals, CREAF. Bellaterra.

PONS, X. \& L. SOLÉ SUGRAÑES.1994. A simple radiometric correction model to improve automatic mapping of vegetation from multispectral satellite data. Remote Sensing of Environment, 48:191-204.

REVENGA, C.,I. CAMPBELL, R. ABELL, P. DE VILLIERS \& M. BRYER. 2005. Prospects for monitoring freshwater ecosystems towards the 2010 targets. Philosophical Transactions of the Royal Society B-Biological Sciences, 360(1454): 397413.

SACKS, L. A., J. S. HERMAN, L. F. KONIKOW \& A. L. VELA. 1992. Seasonal dynamics of groundwater-lake interactions at Doñana National Park, Spain. Journal of Hydrology, 136: 123-154.

SERRANO, L. \& L. SERRANO. 1996. Influence of groundwater exploitation for urban water supply on temporary ponds from the Doñana National Park (SW Spain). Journal of Environmental Management, 46: 229-238.

SERRANO,L. \& M. ZUNZUNEGUI. 2008. The relevance of preserving temporary ponds during drought: hydrological and vegetation changes over a 16-year period in the Doñana National Park (south-west Spain). Aquatic Conservation: Marine and Freshwater Ecosystems, 18: 261-279.

SERRANO, L., M. M. REINA, G. MARTIN, I. REYES \& A. ARECHEDERRA. 2006. The Aquatic Systems of Doñana (SW Spain): Watersheds and Frontiers. Limnetica, 25: 11-32.

SILJESTROM, P., A. MORENO, L. V. GARCÍA \& L. CLEMENTE. 1994. Doñana National Park (SW Spain): Geomorphological characterization 
through a soil-vegetation study. Journal of Arid Environments, 26: 315-323.

TOJA, J. 2006. Los ecosistemas acuáticos de Doñana. In: Doñana, Water and Biosphere. F. García Novo \& C. Marín Cabrera (eds.): 205-212. Spanish Ministry of the Environment, Madrid.

VALVERDE, J. A. 1958. An ecological sketch of the Coto Doñana. British Birds, 51: 1-23.

VALVERDE, J. A. 2004. Memorias de un biólogo heterodoxo. IV. La aventura de Doñana. Cómo crear una reserva. Editorial Quercus V\&V. Madrid.

VELA, A., RODRÍGUEZ, J. \& J. L. TENAJAS. 1991. Análisis de los efectos de la explotación del acuífero costero en las proximidades del Parque
Nacional de Doñana (Huelva). XXIII Proceedings of the International Association of Hydrogeology: Aquifer Overexploitation, 1, International Association of Hydrology: Puerto de la Cruz, Canary Islands, Spain; 179-182.

WIGGINS, G. B., R. J. MACKAY \& I. M. SMITH, 1980. Evolutionary and ecological strategies of animals in annual temporary pools. Archiv für Hydrobiologie, 58(Suppl): 97-206.

ZUNZUNEGUI, M., M. C. DÍAZ BARRADAS \& F. GARCÍA-NOVO. 1998. Vegetation fluctuation in Mediterranean dun ponds in relation to rainfall variation and wáter extraction. Applied Vegetation Science, 1: 151-160. 